\title{
Measuring Modified Mass Energy Equivalence in Nutritional Epidemiology: A Proposal to Adapt the Biophysical Modelling Approach
}

\author{
Azizur Rahman ${ }^{1}$ and Md. Abdul Hakim²,* \\ ${ }^{1}$ School of Computing and Mathematics, Charles Sturt University, Wagga Wagga, New South Wales, \\ Australia \\ ${ }^{2}$ Department of Food Technology and Nutritional Science, Mawlana Bhashani Science and Technology \\ University, Tangail, Bangladesh
}

\begin{abstract}
The calculation of net dietary energy is in great triumph on the helm of designing an apt dieting for both the therapeutic and normal diet. There are some procedures in this connection in nutritional science which is relatively time consuming, laboratory tests induced and often the misleading data contributors in view of assuring balanced dieting. The dietician is often at bay to approve an exact dieting to sustain health and nutritional soundness adhering to the existing dietary energy measuring methods because the frequently using methods are not informing the net dietary energy level required at all in correct amount for the sample at a population in a community. The aim of the current study is to make a dot over these ongoing panics exploring an easy and accurate way in prescribing a confounding free diet. The study can divulge an open secret in measuring net dietary energy which is mandatory for dieting practices worldwide to resist the possible health horrors in nutritional epidemiology. The study finding is the Modified Mass Energy Equivalence [equation (xi)] can be an outstanding biophysical model in measuring net dietary energy as a dieting tool in health pedagogy of health science.
\end{abstract}

Keywords: Mass Energy Equivalence, Health Pedagogy, Biophysical Modeling, Nutritional Epidemiology, Health Physics.

\section{INTRODUCTION}

About 2 billion people around the world suffering from different forms of malnutrition [1]. Malnutrition is an underlying cause of death of about 2.6 million children each year-a third of child deaths globally $[2,3]$.

Childhood malnutrition is leading the stunted growth and increasing mortality and morbidity [4-7] which affect the survival opportunities of adults in their later life [8]. About four of each five malnourished children abide in South-East-Asian region contributing about $83 \%$ of their deaths due to mild to moderate malnutrition $[9,10]$. Malnutrition in developing countries seeing because of to poverty, household food insecurity, gender bias, population pressure, food taboos, health, hygiene and nutritional negligence, famine and man-made disasters [11-17]. Malnutrition also occurring for intra-family feud, lower class livelihood, child abuse, deprivation of schooling opportunity and consequence of faulty family planning practices in their families [18-22]. These nutritional giant is engulfing the world's population [23] and therefore initiatives ahead of proper diet planning for the population is in galore need to shirk these malnutrition facing factors [24].

*Address correspondence to this author at the Department of Food Technology and Nutritional Science, Mawlana Bhashani Science and Technology University, Tangail, Bangladesh; E-mail: hakimaffairs@gmail.com
Therefore, the present was conducted in search of an effective dieting tool which can help the dietician to plan the proper dieting for both the therapeutic and normal diet aiming to turn tail the ongoing malnutrition headache across the globe [25] and the government and different international and national NGOs should organize health and nutritional campaigning to aid the population to practice a healthy diet using the implementing polity of this research discovered Modified Mass Energy Equivalence for health physics.

\section{METHODOLOGY}

The study was a cross-sectional study conducted using the statistical secondary data analysis technique. The data were collected from the world's most famous equation $E=\mathrm{mc}^{2}$ of the physicist Albert Einstein, unit multiplier, fuel factor and the mass of consuming nutrients. The DIT concept in nutritional field and numeric value of $\pi$ in mathematical field were also the data to undergo in analyzing all the data using mathematical modeling to hit upon a trendy and time saving biophysical modeling to calculate net dietary energy required for individuals in the communities.

\section{RESULTS}

Antoine Laurent Lavoisier, a philopher and a chemist discovered the Law of Conservation of Mass 
$[26,27]$ in 1785 stating the matter $[28]$ is neither created nor destroyed in a chemical reaction [29] and Julius Robert Mayer, a physicist discovered the Law of Conservation of Energy in 1842 searching out the First Law of Thermodynamics [30] stating the energy [31,32] is neither created nor destroyed in an isolated system.

Albert Einstein, a German-born physicist announced the Law of Conservation of Mass Energy [33-35] as rule of the combination of the duo laws naming the Law of Conservation of Mass and the Law of Conservation of Energy indicating the total amount of mass and energy in the universe is constant and hence the Law of Conservation of Mass Energy is called Mass Energy Equivalence [36] as a rule of the following mathematical melody,

$E=m c^{2} ;$

Where,

$\mathrm{m}=$ mass of a matter,

$\mathrm{c}=$ speed of light in a vacuum (about $3 \times 10^{8} \mathrm{~ms}^{-1}$ ) and

$E=$ energy of an isolated system.

The value of $c^{2}$ on the right side of the equation (i) is a unit multiplier [37] which take on different gestures in different isolated systems and this equation can steal into the health physics to measure dietary energy $[38,39]$ content of foods taking the puppet in the hand of fuel factors of different components of foods in diet planning.

Let consider the fuel factors of carbohydrate, protein, fat and alcohol be $f_{c}, f_{p}, f_{f}$ and $f_{a} k c a l g^{-1}$ to be responsible to yield $\left(E_{d}\right)_{c},\left(E_{d}\right)_{p},\left(E_{d}\right)_{f}$ and $\left(E_{d}\right)_{a}$ kcal of dietary energy for corresponding consumption of $m_{c}$, $m_{p}, m_{f}$ and $m_{a} g$ of carbohydrate, protein, fat and alcohol respectively in the diet.

So, considering the equation (i) in dieting,

$\left(E_{d}\right)_{c}=f_{c} m_{c}$

$\left(E_{d}\right)_{p}=f_{p} m_{p}$

$\left(E_{d}\right)_{f}=f_{f} m_{f}$

$\left(E_{d}\right)_{a}=f_{a} m_{a}$

Adding the equations (ii), (iii), (iv) and (v),

$\left(E_{d}\right)_{c}+\left(E_{d}\right)_{p}+\left(E_{d}\right)_{f}+\left(E_{d}\right)_{a}=f_{c} m_{c}+f_{p} m_{p}+f_{f} m_{f}+f_{a} m_{a}$
The carbohydrate, protein and fat among the six components of foods and alcohol yield the dietary energy through the metabolism $[40,41]$ process and therefore the following biophysical myth is appeared attending to the left side of equation (vi),

$E_{d}=\left(E_{d}\right)_{c}+\left(E_{d}\right)_{p}+\left(E_{d}\right)_{f}+\left(E_{d}\right)_{a} ;$

Where,

$E_{d}=$ Dietary energy in the diet

Taking equation (vii) inflowing into the equation (vi),

$E_{d}=f_{c} m_{c}+f_{p} m_{p}+f_{f} m_{f}+f_{a} m_{a}$

The numeric value of fuel factors of carbohydrate, protein, fat and alcohol representing $f_{c}, f_{p}, f_{f}$ and $f_{a}$ are 4 , 4,9 and $7 \mathrm{kcal} \mathrm{g}^{-1}[42,43]$. Inserting these values into the equation (viii),

$$
\begin{aligned}
E_{d} & =4 m_{c}+4 m_{p}+9 m_{f}+7 m_{a} \\
& =4 m_{c}+4 m_{p}+4 m_{f}+5 m_{f}+4 m_{a}+3 m_{a} \\
& =4 m_{c}+4 m_{p}+4 m_{f}+4 m_{a}+5 m_{f}+3 m_{a} \\
& =4\left(m_{c}+m_{p}+m_{f}+m_{a}\right)+5 m_{f}+3 m_{a} \\
& =4 \times 7 / 22 \times 22 / 7\left(m_{c}+m_{p}+m_{f}+m_{a}\right)+5 \times 7 / 22 \times 22 / 7 m_{f} \\
+3 \times 7 / 22 \times 22 / 7 m_{a} & \\
& =1.27 \pi\left(m_{c}+m_{p}+m_{f}+m_{a}+1.6 \pi m_{f}+\pi m_{a}\right.
\end{aligned}
$$
(Putting the value of $\pi[44-46]$ )

$$
=\pi\left[1.27\left(m_{c}+m_{p}+m_{f}+m_{a}\right)+1.6 m_{f}+m_{a}\right]
$$

The net dietary energy gained by the body memorizing the DIT concept [47-49] according to the following equation in nutrition,

$$
\begin{aligned}
\left(E_{d}\right)_{n} & =E_{d}-D I T \\
& =E_{d}-10 \% \text { of } E_{d} \\
& =(1-0.1) E_{d} \\
& =0.9 E_{d} ;
\end{aligned}
$$

Where,

$\left(E_{d}\right)_{n}=$ Net dietary energy

So, the following equation is derived through inserting the equation (ix) into the equation (x),

$\left(E_{d}\right)_{n}=0.9 \pi\left[1.27\left(m_{c}+m_{p}+m_{f}+m_{a}\right)+1.6 m_{f}+m_{a}\right]$

Therefore, the equation (xi) is the Modified Mass Energy Equivalence for health physics applicable to measure the net dietary energy as a dieting tool in health science. 


\section{DISCUSSION}

Human health is the level of function or metabolic ability of individuals or communities to adapt and selfmanage during facing physical, mental and social challenges [50]. The WHO defines health in its broader sense in its 1948 constitution as "a state of complete physical, mental, and social well-being and not merely the absence of disease or infirmity" [51]. To maintain healthy health is really harder due to different physical, social, economic and environmental affecting factors. The people are often deprived of their country's constitution valid basic health, hygiene, nutritional care and shelter [52]. The population are want of balanced diet in order to the dieting malpractices and the dieticians are in quest of a time saving and easy method in measuring net dietary energy required for the observance of healthy population [51] in the community. Different health and nutritional hotch potch creating factors such as the DIT [53-55], fuel factor and the information gap between dietary energy $E_{d}$ and net dietary energy $\left(E_{d}\right)_{n}$ are also in existence in the branch of nutritional epidemiology. The engulfing methods are only considering the fuel factor of the nutrients naming carbohydrate, protein and fat fighting shy of the adherence of the rampantly consumed alcohol in the developed and also in developing countries in vast amount but ample amount in the countries of containing the pauperism curse. The present study result is cut and dried by adding the fuel factor of alcohol along with another energy yielders like carbohydrate, protein and fat. The $\left(E_{d}\right)_{n}$ measuring technique is cut short using the study result [equation (xi)] for the health and nutritional epidemiologists. The $\left(E_{d}\right)_{n}$ can be calculated by just inserting the mass of the taking nutrients in the equation (xi) cutting loose the confounding creating parameters and this biophysical modeling can give vent to a new modeling in the branch of health physics. This study proposed Modified Mass Energy Equivalence can be a splashing spatial microsimulation modeling [56-60] to be constructive in designing effective policies for the governments and NGOs for environmental and spatial effects across different countries [61-63] in the world to aid healthy dieting practices for keeping sound health. This health microsimulation modeling [biophysical equation (xi)] gained from the carried out study can be an effective tool at the sector of health pedagogy $[64,65]$ in nutritional epidemiology. The study gained biophysical equation can not in the gesture of nutritional astraphobia and this equation can be in galore application in 1/1 nutrition counseling [66] as a practical application in real life in health science and nutritional biostatistics.

\section{CONCLUSION}

Malnutrition is one of the greatest burning issue in health science in both the developed and developing countries. The present study outcome can take a serious turn in evading the malnutrition sorry tales across the globe. This study rendering the Modified Mass Energy Equivalence should be taking into action in designing healthy diet at different demographic sites in the country. So the international and national level big bug policymakers should bear the testimony in making awareness about the Modified Mass Energy Equivalence as a part of effective dieting tools. Future research should adopt this hassle free $\left(E_{d}\right)_{n}$ calculating modeling to explore a new path in health pedagogy for taking intervention in policy designing, analysis and checking spatial effects for health and nutrition condition upgrading bid for all classes' people.

\section{REFERENCES}

[1] IFAD/FAO/WFP. The State of Food Insecurity in the World 2011, In Rome, Italy: FAO.

[2] UN inter-agency Group for Child Mortality Estimation. Levels and Trends in Child Mortality: Report 2011, New York: UNICEF.

[3] Black RE, Allen LH, Bhutta ZA, et al. Maternal and child undernutrition: global and regional exposures and health consequences. The Lancet 2008; 371(9608): 243-60. http://dx.doi.org/10.1016/S0140-6736(07)61690-0

[4] Megabiaw B, Rahman A. Prevalence and determinants of chronic malnutrition among under-5 children in Ethiopia. International Journal of Child Health and Nutrition 2013; 2(3): 230-236.

http://dx.doi.org/10.6000/1929-4247.2013.02.03.5

[5] Hakim MA, Kamruzzaman M. Nutritional Status of Preschoolers in Four Selected Fisher Communities. American Journal of Life Sciences 2015; 3(4): 332-336. http://dx.doi.org/10.11648/j.ajls.20150304.22

[6] Rahman A, Hakim MA. Malnutrition Prevalence and Health Practices of Homeless Children: A Cross-Sectional Study in Bangladesh. Science Journal of Public Health 2016; 4(1-1): 10-15.

[7] Genton B, Al-Yaman F, Ginny M, Taraika J, Alpers MP Relation of anthropometry to malaria morbidity and immunity in Papua New Guinean. Am J Clin Nutr 1998; 68: 734-41.

[8] Rahman A, Chowdhury S. Determinants of chronic malnutrition among preschool children in Bangladesh. Journal of Biosocial Science, 2007; 39(2): 161-173. http://dx.doi.org/10.1017/S0021932006001295

[9] UNICEF. Malnutrition in South Asia; A Regional Profile, UNICEF report, 1997; p. 8.

[10] Rahman A, Chowdhury S, Hossain D. Acute malnutrition in Bangladeshi children: levels and determinants. Asia Pacific Journal of Public Health 2009; 21(1): 294-302. http://dx.doi.org/10.1177/1010539509335399

[11] Hakim MA, Talukder MJ, Islam MS. Nutritional Status and Hygiene Behavior of Government Primary School Kids in 
Central Bangladesh. Science Journal of Public Health 2015; 3(5): 638-642.

http://dx.doi.org/10.11648/j.sjph.20150305.17

[12] Ghosh S, Shah D. Nutritional Problems in Urban Slum Children. Indian Pediatrics 2004; 41(7): 682-696.

[13] Kamruzzaman M, Hakim MA. Child Criminalization at Slum areas in Dhaka City. American Journal of Psychology and Cognitive Science 2015; 1(4): 107-111.

[14] Fakir AMS, Rahman MW. Determinants of malnutrition among urban slun children in Bangladesh. Health Educ Rev 2015; 5: 22.

[15] Hakim MA, Rahman A. Health and Nutritional Condition of Street Children of Dhaka City: An Empirical Study in Bangladesh. Science Journal of Public Health 2016; 4(1-1): 6-9.

[16] Alam MA, Hakim MA, Rouf MA, Haque MO, Ali ME, Zaidul ISM. Nutritional status of urban slum children below five years: Assessment by anthropometric measurements with special reference to socioeconomic status. Journal of Food Agriculture and Environment 2011; 9(2): 85-90.

[17] Hakim MA, Talukder MJ. An Assessment of Health Status of Street Children in Tangail, Bangladesh. Science Journal of Public Health 2016; 4(1-1): 1-5.

[18] Kamruzzaman M, Hakim MA. Livelihood Status of Fishing Community of Dhaleswari River in Central Bangladesh. International Journal of Bioinformatics and Biomedical Engineering 2016; 2(1): 25-29.

[19] Weitzmawqn M. Excessive school absence. Advances Develop Behav Pediatr 1987; 8: 151-78.

[20] Kamruzzaman M, Hakim MA. Family Planning Practices among Married Women Attending Primary Health Care Centers in Bangladesh. International Journal of Bioinformatics and Biomedical Engineering 2015; 1(3): 251255.

[21] Kuddus A, Rahman A. Human Rights Abuse: A Case Study on Child Labor in Bangladesh. International Journal of Management and Humanities 2015; 1(8): 1-4.

[22] Kamruzzaman M, Hakim MA. Socio-economic Status of Child Beggars in Dhaka City. Journal of Social Sciences and Humanities 2015; 1(5): 516-520.

[23] Hoddinott J, Rosegrant M, Torero M. Challenge Paper: Hunger and Malnutrition 2012.

[24] Rahman A. Significant Risk Factors for Childhood Malnutrition: Evidence from an Asian Developing Country. Science Journal of Public Health 2016; 4(1-1): 16-27.

[25] Ending Malnutrition by 2020: an Agenda for Change in the Millennium. Final Report to the ACC/SCN by Commission on the Nutrition Challenges of the $21^{\text {st }}$ Century, February 2000.

[26] Jammer M. Concept of Mass in Classical and Modern Physics, New York: Dover, 1997.

[27] Kane G. The Mysteries of Mass. Scientific American (Nature America, Inc.), 2008; p. 32-39.

[28] Walker SM, King A. What is Matter? Lerner Publications, 2005; p. 7.

[29] IUPAC. Compendium of Chemical Terminology, $2^{\text {nd }}$ edn. (The Gold Book), 1997. Online corrected version: chemical reaction, 2006.

[30] Planck M. Treatise on Thermodynamics, third edition translated by A. Ogg from the seventh German edition, Longmans, Green and Co., London, 1923/1927; p. 40.

[31] Kittel C, Kroemer H. Thermal Physics. Macmillan, 1980.

[32] Smith C. The Science of Energy - a Cultural History Physics in Victorian Britain. The University of Chicago Press, 1998.

[33] Einstein A. Ist dies Tragheit eines Korpers von seinem Energieinhalt abhangig? Annalen der Physik 1905; 18: 639643.

http://dx.doi.org/10.1002/andp.19053231314
[34]

Einstein A. Uber dies vom Relativitatsprinzip geforderte Tragheit der Energie. Annalen der Physik 1907; 328(7): 371384.

http://dx.doi.org/10.1002/andp.19073280713

[35] Schwartz HM. Einstein's comprehensive 1907 essay on relativity, part II. American Journal of Physics 1977; 45(9) 811-817.

http://dx.doi.org/10.1119/1.11053

[36] Sadava D, Orians G. Life: The Science of Biology. New York: W. H. Freeman and Co. 2000; p. 887.

[37] Bela B, Colon J. Introduction to Soil Mechanics. John Wiley and Sons, 2013; p. 9.

[38] Ledikwe JH, Blanck HM, Kettel KL, Serdula MK, Seymour JD, Tohill BC, Rolls BJ. Dietary energy density is associated with energy intake and weight status in US adults. Am J Clin Nutr 2006; 83(6): 1362-8.

[39] Reedy J, Susan M, Smith K. Dietary Sources of Energy, Solid Fats, and Added Sugars among Children and Adolescents in the United States. J Am Diet Assoc 2010; 110(10): 1477-84.

http://dx.doi.org/10.1016/j.jada.2010.07.010

[40] Ebenhoh O, Heinrich R. Evolutionary optimization of metabolic pathway. Bull Math Biol 2001; 63(1): 21-25. http://dx.doi.org/10.1006/bulm.2000.0197

[41] Ganong WF. Review of Medical Physiology (20 ${ }^{\text {th }}$ edn), 2001; p. 271.

[42] Joshi SA. Nutrition and Dietetics ( $2^{\text {nd }}$ edn.), 2002; p. 31

[43] Mitchell MC, Herlong HF. Alcohol and nutrition: calorie value, bioenergies and relationship to liver damage. Annu Rev Nutr 1986; 6: 457-74. http://dx.doi.org/10.1146/annurev.nu.06.070186.002325

[44] Gupta RC. On the remainder term in the Madhava-Leibniz's series. Ganita Bharti 1992; 14(1-4): 68-71.

[45] George E, Askey AR, Roy R. Special Functions. Cambridge University Press, 1999; p. 58.

[46] Bailey D, Borwein J, Borwein P, Plouffe S. The Quest for Pi. The Mathematical Intelligencer 1997; 19(1): 50-56. http://dx.doi.org/10.1007/BF03024340

[47] Golijan EF. Rapid Review Pathology. Elsevier Health Sciences. 2013; p. 174.

[48] Hakim MA. Physicochemical Properties of Dhania Honey. American Journal of Food Science and Nutrition Research 2015; 2(5): 145-148.

[49] Denzer CM, Young CG. The effect of résistance exercise on the thermal effect of food. International Journal of Sports Nutrition and Exercise Metabolism 2003; 13(3): 396-402.

[50] Huber M, Knottnerus JA, Green L, van der Horst AR, Kromhout D, Smid H. BMJ 2011; 343(d4163).

[51] WHO. Constitution of the World Health, 2006.

[52] Hakim MA. Nutrition on malnutrition helm, nutrition policy in fool's paradise. The Daily Observer, 2015. Available on http: //www.observerbd.com/2015/09/20/111732.php. (Accessed on September 20, 2015).

[53] Huq AKO. Human Nutrition and Applied Dietetics ( $1^{\text {st }}$ edn) 2012; p. 37

[54] Linkon KMMR, Prodhan UK, Hakim MA, Alim MA. Study on the Physicochemical and Antioxidant Properties of Nigella Honey. International Journal of Nutrition and Food Sciences 2015; 4(2): 137-140. http://dx.doi.org/10.11648/j.ijnfs.20150402.13

[55] Glickman N, Mitchell HH. The total specific dynamic action of high-protein and high-carbohydrate diets of human subjects. The Journal of Nutrition 1948; 36(1): 41-57.

[56] Rahman A, Harding A, Tanton R, Liu S. Methodological issues in spatial microsimulation modelling for small area estimations. International Journal of Microsimulation 2010; $3(2): 3-22$ 
[57] Islam D, Ashraf M, Rahman A, Hasan R. Quantitative Analysis of Amartya Sen's Theory: An ICT4D Perspective. International Journal of Information Communication Technologies and Human Development 2015; 7(3): 13-26. http://dx.doi.org/10.4018/IJICTHD.2015070102

[58] Rahman A, Harding A. Spatial analysis of housing stress estimation in Australia with statistical validation. Australasian Journal of Regional Studies 2014; 20(3): 452-486.

[59] Rahman A, Harding A, Tanton R, Liu S. Simulating the characteristics of populations at the small area level: New validation techniques for a spatial microsimulation model in Australia. Computational Statistics and Data Analysis 2013; 57(1): 149-165.

http://dx.doi.org/10.1016/j.csda.2012.06.018

[60] Rahman A, Harding A. Some health related issues in Australia and methodologies for estimating small area health related characteristics. Online Working Paper Series 2010; WP-15, NATSEM, University of Canberra. p. 1-59.

[61] Phill M. Small area housing stress estimation in Australia: Microsimulation modeling and statistical reliability, University of Canberra, Australia, 2011.
[62] Rahman A, Upadhyay S. A Bayesian reweighting technique for small area estimation. Current Trends in Bayesian Methodology with Applications, CRC Press, London, 2015; p. 503-519.

http://dx.doi.org/10.1201/b18502-25

[63] Rahman A. Small area estimation through spatial microsimulation models: Some methodological issues, Paper presented at the $2^{\text {nd }}$ General Conference of the International Microsimulation Association, The National Conference Centre Ottawa, Canada, 2009; p. 1- 45 (June 8 to 10).

[64] Karsten K. Educational Theory as Tropical Rheotic: The Concepts of Pedagogy of Johann Freidrich Herbert and Freidrich Schleiermacher. Studies in Philosophy and Education 2012; 31(1): 265-273.

[65] Poole SA, Hart CN, Jelalian E, Raynor HA. Relationship between dietary energy and dietary quality in overweight young children: a cross-sectional analysis. Pediatric Obesity 2016; 11(2): 128-135.

http://dx.doi.org/10.1111/ijpo.12034

[66] Hakim MA. Malnutrition Prevalence and Nutrition Counseling in Developing Countries: A Case Study. International Journal of Nursing and Health Science 2016; 3(3): 19-22. 